\title{
Efficient Education Policy - A Second-Order Elasticity Rule
}

\author{
Wolfram F. Richter
}

CESIFO WORKING PAPER NO. 2969

CATEgory 1: Public FinANCE

ORIGINAL VERSION: FEBRUARY 2010

THIS VERSION: MARCH 2011

An electronic version of the paper may be downloaded

- from the SSRN website:

- from the RePEc website:

- from the CESifo website:

www.SSRN.com

www.RePEc.org

www.CESifo-group.org/wp 


\title{
Efficient Education Policy - A Second-Order Elasticity Rule
}

\begin{abstract}
Assuming a two-period model with endogenous choices of labor, education, and saving, efficient education policy is characterized for a Ramsey-like scenario in which the government is constrained to use linear instruments. It is shown that education should be effectively subsidized if, and only if, the elasticity of the earnings function is increasing in education. The strength of second-best subsidization increases in the elasticity of the elasticity of the earnings function. This second-order elasticity rule extends the well-known RamseyBoiteux inverse elasticity rule.
\end{abstract}

JEL-Code: H21, I28, J24.

Keywords: endogenous choice of education, second-best efficient taxation, linear instruments, finite periods, Ramsey’s Rule, inverse elasticity rule.

\author{
Wolfram F. Richter \\ TU Dortmund University \\ Department of Economics \\ 44221 Dortmund \\ Germany \\ Wolfram.Richter@tu-dortmund.de
}

Forthcoming in FinanzArchiv / Public Finance Analysis.

Helpful comments of two anonymous referees are gratefully acknowledged. 


\section{Introduction}

The inverse elasticity rule states that optimally chosen commodity tax rates should be inversely related to the price elasticities of demand. The rule is usually attributed to Ramsey (1927), but a structurally equivalent formula was derived independently by Boiteux (1956) for the problem of optimal monopoly pricing. The assumptions underlying optimal taxation in Ramsey's tradition have been criticized from a conceptual point of view. Still, there will be no introductory course in optimal taxation that does not mention the rule. This paper demonstrates how the rule has to be extended if it is to guide efficient education policy in Ramsey's tradition. It is shown that the standard role taken by the elasticity of demand or supply has to be replaced with the elasticity of elasticity - also called second-order elasticity in what follows - if the rule is to apply to education. The extended rule calls for subsidizing education effectively if, and only if, the elasticity of the earnings function is increasing in education. In particular, the strength of subsidization should increase in the function's secondorder elasticity.

This note is structured as follows. Section 2 sets up the model of a representative taxpayer. Section 3 derives the extended elasticity rule for education. Section 4 provides the proof.

\section{A Representative-Household Model}

The model is taken from Richter (2009). It assumes a representative taxpayer living for two periods and deriving strictly increasing utility $U$ from consumption $C_{i}$ and strictly decreasing disutility from nonleisure time $L_{i}$ in periods $i=1$, 2 . The function $U=U\left(C_{1}, C_{2}, L_{1}, L_{2}\right)$ is strictly quasi-concave. $L_{2}$ is identical with the second-period labor supply. By contrast, only $L_{1}-E$ is time spent in the market, while $E$ is time spent on education. The first-period labor supply earns a constant wage rate $\omega_{1}$; the return to second-period labor depends on the amount of education. It is paid $\omega_{2} H(E)$, where $\omega_{2}$ is constant while the earnings function $H(E)$ displays positive but diminishing returns, $H^{\prime}>0>H^{\prime \prime}$. The quantity $L_{2}$ is interpreted as qualified labor. Likewise, the quantities $L_{1}-E$ and $L_{1}$ are interpreted as nonqualified labor and nonqualified nonleisure, respectively. Education causes an opportunity cost in forgone earnings and a monetary cost of tuition. Both costs are assumed to be linear in time. The cost of foregone earnings is denoted by $\omega_{1} E$, and the cost of tuition is denoted by $\varphi E$. The share of first-period income that is spent neither on education nor on consumption is saved: 


$$
S=\omega_{1}\left(L_{1}-E\right)-\varphi E-C_{1}=\omega_{1} L_{1}-\left(\omega_{1}+\varphi\right) E-C_{1}
$$

By way of normalization, the price of consumption is set equal to one. The gross rate of return to saving is denoted by $\rho$. Second-period consumption is constrained by income earned:

$$
C_{2}=\rho S+\omega_{2} H(E) L_{2}
$$

Substituting for $S$ in (1) and (2) yields the lifetime budget constraint:

$$
C_{1}+C_{2} / \rho=\omega_{1} L_{1}+\omega_{2} H(E) L_{2} / \rho-\left(\varphi+\omega_{1}\right) E
$$

The sole objective of this note is to extend the inverse elasticity rule to education. For this purpose consideration is restricted to utility functions that are quasilinear in first-period consumption and additive in periodic sub-utilities:

$$
U\left(C_{1}, C_{2}, L_{1}, L_{2}\right)=C_{1}-V_{1}\left(L_{1}\right)+U\left(C_{2}, L_{2}\right)
$$

The function $V_{1}$ is strictly increasing and strictly convex. The representative taxpayer maximizes (4) in $C_{1}, C_{2}, L_{1}, L_{2}, E \geq 0$ subject to $L_{1} \geq E$ and (3). In what follows it is assumed that this maximization is well behaved. This means that there exists an interior unique solution that is differentiable in $\omega_{1}, \omega_{2}, \rho, \varphi$ and that the second-order conditions are fulfilled. The first-order conditions are

$$
\begin{aligned}
& \omega_{1}=V_{1}^{\prime}\left(L_{1}\right), \quad \rho=1 / U_{C}, \\
& U_{L}+\omega_{2} H(E) / \rho=0, \quad \omega_{2} H^{\prime}(E) L_{2} / \rho=\omega_{1}+\varphi .
\end{aligned}
$$

The following example satisfies all the assumptions needed in the present study:

- $H(E) \equiv h E^{\bar{\eta}}+H_{0}$ with $h>0,1>\bar{\eta}>0, H_{0} \geq 0$,

- $U\left(C_{2}, L_{2}\right) \equiv u_{C}\left(C_{2}\right)-V_{2}\left(L_{2}\right)$ with $V_{2}^{\prime}>0$,

and some elasticity of the marginal disutility of labor which is sufficiently large at the secondbest level of $L_{2}$ :

- $v_{2} \equiv L_{2} V_{2}^{\prime \prime} / V_{2}^{\prime}>\bar{\eta} /(1-\bar{\eta})$

The case of an increasing elasticity of the earnings function, $\eta \equiv E H^{\prime} / H$, will play a prominent role in the following discussion of second-best policy. Because $\eta=\bar{\eta}\left(1-H_{0} / H(E)\right)$, the specification (7) provides an example of an earnings function featuring an increasing elasticity, $\eta^{\prime}>0$, if and only if $H_{0}>0$. The inequality (8) is needed to 
ensure that the second-order conditions of the taxpayer's maximization are fulfilled. This can be verified as follows. Let

$$
Y\left(L_{2}\right) \equiv \max _{E}\left[\omega_{2} H L_{2} / \rho-\left(\omega_{1}+\varphi\right) E\right]
$$

be the ability-rent income. The second-order condition with respect to $L_{2}$ requires

$$
\begin{aligned}
& 0>Y^{\prime \prime}-V_{2}^{\prime \prime} \underset{(6)}{=}-\frac{\omega_{2}}{\rho} \frac{H^{\prime 2}}{H^{\prime \prime} L_{2}}-V_{2}^{\prime \prime} \underset{(6)}{=}-\frac{V_{2}^{\prime}}{H} \frac{H^{\prime 2}}{H^{\prime \prime} L_{2}}-V_{2}^{\prime \prime} \Leftrightarrow \\
& v_{2}=L_{2} V_{2}^{\prime \prime} / V_{2}^{\prime}>\frac{H^{\prime} E / H}{-H^{\prime \prime} E / H^{\prime}}=\frac{\bar{\eta}}{1-\bar{\eta}} \frac{H-H_{0}}{H} .
\end{aligned}
$$

This follows from (8) and (7).

\section{Second-Best Policy}

The government faces the need to raise an exogenous amount of revenue $G$. Four linear tax instruments are available, each of which is distorting. The taxes are levied on period $i$ 's labor income, on the return to saving, and on the cost of tuition. They are modeled implicitly as the difference between prices before and after taxes. The prices after taxes and subsidies are endogenous and denoted by $\omega_{1}, \omega_{2}, \rho, \varphi$. The prices before taxes and subsidies are exogenous and denoted by $w_{1}, w_{2}, r, f$. Little would change if the wage rate of qualified labor, $w_{2}$, were normalized to one. By way of contrast, the wage rate after tax and subsidy, $\omega_{2}$, cannot be normalized, as it is determined endogenously. The tax on period i's labor income is modeled by $w_{i}-\omega_{i}$, the tax on capital income by $r-\rho$, and the tax on the cost of tuition by $\varphi-f$. It goes without saying that each tax can well take on a negative value so that it is effectively a subsidy. Government's net revenue has to balance the budget:

$$
\begin{aligned}
& \left(w_{1}-\omega_{1}\right)\left(L_{1}-E\right)+(\varphi-f) E+\left[\left(w_{2}-\omega_{2}\right) H(E) L_{2}+(r-\rho) S\right] / r \\
& \underset{(2)}{=}\left(w_{1}-\omega_{1}\right) L_{1}+\left[\left(\varphi+\omega_{1}\right)-\left(f+w_{1}\right)\right] E+\left[\frac{w_{2}}{r}-\frac{\omega_{2}}{\rho}\right] H L_{2}+\left[\frac{1}{\rho}-\frac{1}{r}\right] C_{2}=G .
\end{aligned}
$$

The planner maximizes the representative taxpayer's utility (4) in the quantities $C_{1}, C_{2}, L_{1}, L_{2}, E$ and prices $\omega_{1}, \omega_{2}, \rho, \varphi$ subject to the behavioral constraints (3), (5), (6), and the budget constraint (9). Assume that the planner's maximization is well behaved. The sole 
objective of this note is to characterize efficient policy for education in relation to the taxation of nonqualified labor.

Efficiency is characterized in terms of wedges. Denote by

$$
\begin{aligned}
& \Delta_{L_{1}} \equiv \frac{w_{1}-\omega_{1}}{\omega_{1}} \quad \text { the wedge on nonqualified labor, and by } \\
& \Delta_{E} \equiv \frac{w_{2} H^{\prime} L_{2} / r-f-w_{1}}{\varphi+\omega_{1}} \underset{\text { (6) }}{=} \frac{w_{2} / r}{\omega_{2} / \rho}-\frac{f+w_{1}}{\varphi+\omega_{1}} \quad \text { the wedge on education. }
\end{aligned}
$$

According to (11), the wedge on education equals the difference between two ratios. The first ratio relates present returns before and after taxes and subsidies, and the second ratio relates costs before and after taxes and subsidies. Hence the wedge vanishes if the ratio of returns equals the ratio in costs. Let us speak of effective subsidization if $\Delta_{E}$ is negative. According to (11), a negative value of $\Delta_{E}$ is the combined result of all four policy instruments. Effective subsidization is clearly reached by the statutory subsidization of the cost of tuition. This is however not the only way of reducing $\Delta_{E}$. Other effective means are (i) increasing the tax on nonqualified labor and thus reducing the opportunity cost of education, (ii) reducing the tax on qualified labor and thus increasing the return to education, and finally (iii) taxing saving and thus increasing the return to education.

Denote by

$$
v_{1} \equiv L_{1} V_{1}^{\prime \prime} / V_{1}^{\prime}>0
$$

the elasticity of marginal disutility of nonqualified labor, i.e., the reciprocal of the wage elasticity, and by

$$
\eta_{\eta} \equiv E \eta^{\prime} / \eta
$$

the second-order elasticity of the earnings function.

Elasticity Rule for Education: If $\omega_{1}, \omega_{2}$, and $\varphi$ are optimally chosen, then

$$
\frac{\Delta_{E}}{\Delta_{L_{1}}}=-\frac{\eta_{\eta}}{v_{1}} .
$$


Note that the rule holds even if the planner does not optimize with respect to $\rho$. Saving does not need to be taxed efficiently, and yet education policy should respect (12). A straightforward implication is that education should not be distorted $\left(\Delta_{E}=0\right)$ if the elasticity of the earnings function, $\eta$, is constant. This is a well-known result, also named the education efficiency proposition (Richter, 2009). It had been derived before in more elaborate models with heterogeneous taxpayers by Bovenberg and Jacobs (2005) and Jacobs and Bovenberg (2008). Another implication of (12) is that education should be subsidized if the elasticity of the earnings function is increasing.

Related results have been derived by Braun (2009) and Richter (2009). What has been lacking so far is the simple elasticity formula (12), which allows one to characterize efficient subsidization by means of the second-order elasticity of the earnings function. For the purpose of interpreting (12), assume that nonqualified labor income is taxed $\left(\Delta_{L_{1}}>0\right)$ and that the elasticity of the earnings function is increasing. Then (12) suggests that the second-best tax on (nonqualified) labor should vary inversely with the wage elasticity. This is the known part of the elasticity rule. The innovative part is the suggestion that the effective subsidization of education should increase monotonically in the second-order elasticity of education.

The recommendation to effectively subsidize education raises the question of how to translate it into specific tax and subsidy rates. Unfortunately, no simple formula exists for the Ramsey framework. As one may well suppose, the efficient set of tax and subsidy rates strongly depends on the specification of the taxpayer's utility function. There is only one known robust result. This states that qualified labor should be less distorted than nonqualified labor (Richter, 2009). It holds for arbitrary utility and earnings functions.

\section{Proof}

The proof is fairly straightforward. Start by simplifying the planner's problem. Replace $\omega_{1}$ by $V_{1}^{\prime}$, and drop the constraint $\rho=1 / U_{C}$ because the proof does not rely on any derivatives with respect to $\rho, C_{2}, L_{2}$. The restated planner's problem is:

$$
\max \left[L_{1} V_{1}^{\prime}\left(L_{1}\right)+\omega_{2} H(E) L_{2} / \rho-\left(\varphi+V_{1}^{\prime}\left(L_{1}\right)\right) E-V_{1}\left(L_{1}\right)+U\left(C_{2}, L_{2}\right)-C_{2} / \rho\right]
$$

in $\varphi, L_{1}, \omega_{2}, E$ subject to

$$
U_{L}\left(C_{2}, L_{2}\right)+\omega_{2} H(E) / \rho=0 \text {, }
$$




$$
\begin{aligned}
\omega_{2} H^{\prime}(E) L_{2} / \rho & =\varphi+V_{1}^{\prime}\left(L_{1}\right) \\
\left(w_{1}-V_{1}^{\prime}\left(L_{1}\right)\right) L_{1} & +\left[\left(\varphi+V_{1}^{\prime}\left(L_{1}\right)\right)-\left(f+w_{1}\right)\right] E \\
+ & \left(\frac{w_{2}}{r}-\frac{\omega_{2}}{\rho}\right) H(E) L_{2}+\left[\frac{1}{\rho}-\frac{1}{r}\right] C_{2}=G . \quad(\gamma)
\end{aligned}
$$

The first-order conditions with respect to $\varphi, L_{1}, \omega_{2}, E$ are as follows:

$$
\begin{array}{ll}
\frac{\partial}{\partial \varphi}: & (\gamma-1) E=\mu ; \\
\frac{\partial}{\partial L_{1}}: & \gamma\left(w_{1}-V_{1}^{\prime}\right) \underset{(17)}{=}(\gamma-1) L_{1} V_{1}^{\prime \prime} ; \\
\frac{\partial}{\partial \omega_{2}}: & \lambda \underset{(17)}{=}(\gamma-1)(1-\eta) L_{2} ; \\
\frac{\partial}{\partial E}: & \gamma\left[f+w_{1}-w_{2} H^{\prime} L_{2} / r\right]_{(17),(19)}^{=}(\gamma-1)\left[\varphi+V_{1}^{\prime}-\eta \omega_{2} H^{\prime} L_{2} / \rho+\omega_{2} H^{\prime \prime} E L_{2} / \rho\right] \\
& \underset{(6)}{=}(\gamma-1)\left[1-\eta+\frac{H^{\prime \prime} E}{H^{\prime}}\right]\left(\varphi+V_{1}^{\prime}\right)=(\gamma-1) \frac{E \eta^{\prime}}{\eta}\left(\varphi+\omega_{1}\right) .
\end{array}
$$

The Lagrange multiplier $\gamma$ is clearly positive. The multiplier $\gamma$ has to be greater than one if $w_{1}$ is to exceed $V_{1}^{\prime}=\omega_{1}$. Dividing (18) by $V_{1}^{\prime}$ and (20) by $\varphi+\omega_{1}$ and dividing the resulting equation (20) by the resulting equation (18) yields (12).

\section{References}

Boiteux, M. (1956), Sur la gestion des monopoles publics astreints à l'équilibre budgétaire, Econometrica 24, 22-40.

Bovenberg, A. L., and Jacobs, B. (2005), Redistribution and Learning Subsidies are Siamese Twins, Journal of Public Economics 89, 2005-2035.

Braun, C. (2009), Optimal Taxation of Education with an Initial Endowment of Human Capital, TU Dortmund University, mimeo.

Jacobs, B., and Bovenberg, A. L. (2008), Optimal Taxation of Human Capital and the Earnings Function, CESifo Working Paper No. 2250.

Ramsey, F.P. (1927), A Contribution to the Theory of Taxation, Economic Journal 37, 47-61.

Richter, W.F. (2009), Taxing Education in Ramsey’s Tradition, Journal of Public Economics 93, 1254-1260. 


\section{CESifo Working Paper Series}

for full list see www.cesifo-group.org/wp

(address: Poschingerstr. 5, 81679 Munich, Germany, office@cesifo.de)

2905 Mikael Priks, The Effect of Surveillance Cameras on Crime: Evidence from the Stockholm Subway, December 2009

2906 Xavier Vives, Asset Auctions, Information, and Liquidity, January 2010

2907 Edwin van der Werf, Unilateral Climate Policy, Asymmetric Backstop Adoption, and Carbon Leakage in a Two-Region Hotelling Model, January 2010

2908 Margarita Katsimi and Vassilis Sarantides, Do Elections Affect the Composition of Fiscal Policy?, January 2010

2909 Rolf Golombek, Mads Greaker and Michael Hoel, Climate Policy without Commitment, January 2010

2910 Sascha O. Becker and Ludger Woessmann, The Effect of Protestantism on Education before the Industrialization: Evidence from 1816 Prussia, January 2010

2911 Michael Berlemann, Marco Oestmann and Marcel Thum, Demographic Change and Bank Profitability. Empirical Evidence from German Savings Banks, January 2010

2912 Øystein Foros, Hans Jarle Kind and Greg Shaffer, Mergers and Partial Ownership, January 2010

2913 Sean Holly, M. Hashem Pesaran and Takashi Yamagata, Spatial and Temporal Diffusion of House Prices in the UK, January 2010

2914 Christian Keuschnigg and Evelyn Ribi, Profit Taxation and Finance Constraints, January 2010

2915 Hendrik Vrijburg and Ruud A. de Mooij, Enhanced Cooperation in an Asymmetric Model of Tax Competition, January 2010

2916 Volker Meier and Martin Werding, Ageing and the Welfare State: Securing Sustainability, January 2010

2917 Thushyanthan Baskaran and Zohal Hessami, Globalization, Redistribution, and the Composition of Public Education Expenditures, January 2010

2918 Angel de la Fuente, Testing, not Modelling, the Impact of Cohesion Support: A Theoretical Framework and some Preliminary Results for the Spanish Regions, January 2010

2919 Bruno S. Frey and Paolo Pamini, World Heritage: Where Are We? An Empirical Analysis, January 2010 
2920 Susanne Ek and Bertil Holmlund, Family Job Search, Wage Bargaining, and Optimal Unemployment Insurance, January 2010

2921 Mariagiovanna Baccara, Allan Collard-Wexler, Leonardo Felli and Leeat Yariv, Gender and Racial Biases: Evidence from Child Adoption, January 2010

2922 Kurt R. Brekke, Roberto Cellini, Luigi Siciliani and Odd Rune Straume, Competition and Quality in Regulated Markets with Sluggish Demand, January 2010

2923 Stefan Bauernschuster, Oliver Falck and Niels Große, Can Competition Spoil Reciprocity? - A Laboratory Experiment, January 2010

2924 Jerome L. Stein, A Critique of the Literature on the US Financial Debt Crisis, January 2010

2925 Erkki Koskela and Jan König, Profit Sharing, Wage Formation and Flexible Outsourcing under Labor Market Imperfection, January 2010

2926 Gabriella Legrenzi and Costas Milas, Spend-and-Tax Adjustments and the Sustainability of the Government’s Intertemporal Budget Constraint, January 2010

2927 Piero Gottardi, Jean Marc Tallon and Paolo Ghirardato, Flexible Contracts, January 2010

2928 Gebhard Kirchgässner and Jürgen Wolters, The Role of Monetary Aggregates in the Policy Analysis of the Swiss National Bank, January 2010

2929 J. Trent Alexander, Michael Davern and Betsey Stevenson, Inaccurate Age and Sex Data in the Census PUMS Files: Evidence and Implications, January 2010

2930 Stefan Krasa and Mattias K. Polborn, Competition between Specialized Candidates, January 2010

2931 Yin-Wong Cheung and Xingwang Qian, Capital Flight: China’s Experience, January 2010

2932 Thomas Hemmelgarn and Gaetan Nicodeme, The 2008 Financial Crisis and Taxation Policy, January 2010

2933 Marco Faravelli, Oliver Kirchkamp and Helmut Rainer, Social Welfare versus Inequality Concerns in an Incomplete Contract Experiment, January 2010

2934 Mohamed El Hedi Arouri and Christophe Rault, Oil Prices and Stock Markets: What Drives what in the Gulf Corporation Council Countries?, January 2010

2935 Wolfgang Lechthaler, Christian Merkl and Dennis J. Snower, Monetary Persistence and the Labor Market: A New Perspective, January 2010

2936 Klaus Abberger and Wolfgang Nierhaus, Markov-Switching and the Ifo Business Climate: The Ifo Business Cycle Traffic Lights, January 2010 
2937 Mark Armstrong and Steffen Huck, Behavioral Economics as Applied to Firms: A Primer, February 2010

2938 Guglielmo Maria Caporale and Alessandro Girardi, Price Formation on the EuroMTS Platform, February 2010

2939 Hans Gersbach, Democratic Provision of Divisible Public Goods, February 2010

2940 Adam Isen and Betsey Stevenson, Women's Education and Family Behavior: Trends in Marriage, Divorce and Fertility, February 2010

2941 Peter Debaere, Holger Görg and Horst Raff, Greasing the Wheels of International Commerce: How Services Facilitate Firms’ International Sourcing, February 2010

2942 Emanuele Forlani, Competition in the Service Sector and the Performances of Manufacturing Firms: Does Liberalization Matter?, February 2010

2943 James M. Malcomson, Do Managers with Limited Liability Take More Risky Decisions? An Information Acquisition Model, February 2010

2944 Florian Englmaier and Steve Leider, Gift Exchange in the Lab - It is not (only) how much you give ..., February 2010

2945 Andrea Bassanini and Giorgio Brunello, Barriers to Entry, Deregulation and Workplace Training: A Theoretical Model with Evidence from Europe, February 2010

2946 Jan-Emmanuel De Neve, James H. Fowler and Bruno S. Frey, Genes, Economics, and Happiness, February 2010

2947 Camille Cornand and Frank Heinemann, Measuring Agents' Reaction to Private and Public Information in Games with Strategic Complementarities, February 2010

2948 Roel Beetsma and Massimo Giuliodori, Discretionary Fiscal Policy: Review and Estimates for the EU, February 2010

2949 Agnieszka Markiewicz, Monetary Policy, Model Uncertainty and Exchange Rate Volatility, February 2010

2950 Hans Dewachter and Leonardo Iania, An Extended Macro-Finance Model with Financial Factors, February 2010

2951 Helmuth Cremer, Philippe De Donder and Pierre Pestieau, Education and Social Mobility, February 2010

2952 Zuzana Brixiová and Balázs Égert, Modeling Institutions, Start-Ups and Productivity during Transition, February 2010

2953 Roland Strausz, The Political Economy of Regulatory Risk, February 2010 
2954 Sanjay Jain, Sumon Majumdar and Sharun W. Mukand, Workers without Borders? Culture, Migration and the Political Limits to Globalization, February 2010

2955 Andreas Irmen, Steady-State Growth and the Elasticity of Substitution, February 2010

2956 Bengt-Arne Wickström, The Optimal Babel - An Economic Framework for the Analysis of Dynamic Language Rights, February 2010

2957 Stefan Bauernschuster and Helmut Rainer, From Politics to the Family: How Sex-Role Attitudes Keep on Diverging in Reunified Germany, February 2010

2958 Patricia Funk and Christina Gathmann, How do Electoral Systems Affect Fiscal Policy? Evidence from State and Local Governments, 1890 to 2005, February 2010

2959 Betsey Stevenson, Beyond the Classroom: Using Title IX to Measure the Return to High School Sports, February 2010

2960 R. Quentin Grafton, Tom Kompas and Ngo Van Long, Biofuels Subsidies and the Green Paradox, February 2010

2961 Oliver Falck, Stephan Heblich, Alfred Lameli and Jens Suedekum, Dialects, Cultural Identity, and Economic Exchange, February 2010

2962 Bård Harstad, The Dynamics of Climate Agreements, February 2010

2963 Frederick van der Ploeg and Cees Withagen, Is There Really a Green Paradox?, February 2010

2964 Ingo Vogelsang, Incentive Regulation, Investments and Technological Change, February 2010

2965 Jan C. van Ours and Lenny Stoeldraijer, Age, Wage and Productivity, February 2010

2966 Michael Hoel, Climate Change and Carbon Tax Expectations, February 2010

2967 Tommaso Nannicini and Roberto Ricciuti, Autocratic Transitions and Growth, February 2010

2968 Sebastian Brauer and Frank Westermann, A Note on the Time Series Measure of Conservatism, February 2010

2969 Wolfram F. Richter, Efficient Education Policy - A Second-Order Elasticity Rule, February 2010 